\title{
Pedagogy and Politics: Some Critical Reflections on the Postmodern Turn in Critical Pedagogy 1
}

\section{Dieter Misgeld}

Ontario Institute for Studies in Education

Much has always been expected of education, and this also holds in our present historical epoch, in particular in times of crisis. In North America, especially in the United States, there now is a raging debate about the shortcomings of education, indicating a sense of crisis. It has provoked a variety of responses, reaching from government to the academic world, newspapers, and journals (Bloom, 1987; Searle, 1990). ${ }^{2}$

In North America education is expected to secure competitive economic strength. As larger and larger trading blocs are formed and the world economy is divided up between them, it is believed that only those countries will matter in the future that manage to produce the capacity to compete and survive, or that manage to survive producing the skills and abilities required to survive in global economic competition. Education is assigned this task of establishing among the relevant population a number of sufficiently well-trained people capable of responding to the new harsh conditions.

These novel factors, the end of the Cold War, and the retreat of the Soviet Union from the effort to maintain a position of global influence (or predominance) by military means has had the effect of letting a large set of convictions disintegrate that once accompanied the rise of the modern age and that were still present before the recent end of the global superpower confrontation. These convictions had social progress as their content. We may refer to them with the old term emancipation, emancipation from natural want and social injustice, from the harshness of life dictated by natural conditions and inadequate social responses to it, emancipation, finally, from specific forms of social injustice, such as class, colonial, and gender oppression. ${ }^{3}$

In all these cases education was meant to be an energizing force. First, knowledge was to put humanity in a condition of mastery and power over nature, as Francis Bacon had already envisaged it. And Dewey (1948) praised Bacon as the real predecessor to the modern, the 20th century's pragmatist philosopher's confidence in a practical and interventionist attitude to life. Second, knowledge and education were to 
help the workingman of Marx's time and the subsequent working-class movement develop their aspirations to justice and equality with the more influential classes. ${ }^{4}$ Third, education was to be a major force in the process of decolonization, the shattering of the West European stranglehold over development in Asia, Africa, and Latin America. ${ }^{5}$ And fourth, education and the entry of large numbers of women into higher education were to establish a condition of gender equality. This has been the position of feminism and has been the position of those struggling for the emancipation of women. Indeed, in the case of women education was an important rallying point for the emancipation movement because women were denied the capacity to know as men do; they were denied the capacity of "reason."

Now we cannot help but notice that the force and determination that these energizing convictions once embodied are about to disintegrate. There now is a "plurality" of convictions in the world, which some are inclined to celebrate. But the plurality of convictions I refer to is one of plural versions of uncertainty, self-doubt, and confusion accompanied by the determination to maintain advantages without real resort to conviction. Habermas (1989b) and his postmodernist opponents both are right. We live in an age of the waning of utopian energies. And we may even live in an age during which the entire profile of modernity to which I allude is disintegrating. But if it does, so do most of our predominant and long-valued ideas of education.

Contrary to Dewey's expectation that education would (and could) be the major venue or vehicle of social reform, we now need to give up this belief as expectations for the possibility of progress disintegrate. And it can hardly be expected that these beliefs will survive. Why is this the case? Expectations of progress on a large scale had usually been defined with reference to the release of capacities during the modern age and for mastery of the natural environment through the development of knowledge. Social emancipation, that is, the overcoming of force and suffering in human life, was thought to be achievable as techniques and technologies were invented that permitted the creation of conditions of material security and comfort for ever larger numbers of people. For the Enlightenment, at least in part, these results were thought to be achievable as knowledge developed both of the natural world and of society and of the capacities of the individual human being. ${ }^{7}$

Development is a term that collects all these aspirations around it. It served and still serves as a focus for all the attempts in modern and modernizing societies to discover and use previously unknown potentials, hidden capacities, and yet-to-be-used energies. In our day, development has contracted on the vast global scale to the primacy of economic development. Social and political as well as individual 
psychosocial developments are expected to follow suit. This at least is the perspective that has been applied to entire societies and states by enormously powerful international organizations.

Critics of this position since Hegel and Marx (or even earlier) have argued against this one-sided view. But they frequently have used it as a measure ${ }^{8}$ for dimensions of progress, or of development, that are said to transcend it. These are the dimensions of democratic and social-cultural development, or of moral and political progress: in short, emancipation, to use a rather old-fashioned term.

Thus increasingly our conceptions of progress and development have contracted during the 20th century and drawn away from the older Enlightenment view that progress requires the development of knowledge on a broad scale. The older view that the acquisition of knowledge means emancipation, the victory of reason, and rationality over ignorance and fear is being replaced by the belief that economic progress must come first. The once indispensable connection between emancipation and knowledge is severed. Knowledge and its acquisition, or critical insight and understanding, are no longer desirable, or less so than knowledge that serves economic development or what is presumed to be such. That is why skills training and technical proficiency come first in so much educational planning, as well as the modes of managerial regulation thought to be needed for this form of education (Giroux, 1989; Misgeld, 1985, 1991).

Therefore, it is somewhat misleading, in my view, to argue that we live in a "postmodern age," and that education also has to become "postmodern" (Giroux \& Aronowitz, 1991, Giroux, 1991). We then get the illusion of a process having come to an end that only now is gathering full force, indeed becoming a veritable storm: economic development is to be maintained at all costs, modernity and its promise of emancipation to be reduced to it. And so, for the last time, the promise of universal emancipation underlying so much of the modern age is to be met.

But, of course, the pursuit of this chimerical ideal has little in common with the older idea of universal emancipation from want, suffering, and injustice. All around us the conditions that led to it crumble. The world's population grows at an exponential rate and with it hunger, starvation, disease, malnutrition, infant mortality, and the brutalization of women and of family life. Larger and larger streams of people migrate and seek refuge from conflict and persecution, putting an impossible strain on already scant resources designated for humanitarian aid. Old epidemics return and new ones arise. Soil exhaustion, deforestation and the disappearance of natural resources continue unabated. Ethnic conflicts and ancient hatreds are on the rise. 
Conditions of life in the largest cities become impossible. Many of them disintegrate and for many people life in cities becomes cruel and short.

The progressive ideologies of modernity, from democracy and liberalism to socialism and communism have become empty, lifeless husks of formerly inspiring ideas. It is rare that a people would still be motivated toward a major struggle on their behalf. Knowledge has become an industry, universities centers of frequently exclusive, selfabsorbed discourses and professionalized communication, while the majority of schools twist and turn, indeed frequently wither, under the onslaught of renewed attempts to assign to them the task to do and achieve what the rest of society fails to do and achieve. ${ }^{9}$

This is our condition: It is likely that we face untold forms of destruction, as one already encounters new and ghastly forms of brutality. As members of modern societies on the verge of losing ourselves in a directionless series of reactions to ever more formidable dangers, we must face the disillusioning thought that the end of the modern age may be with us for a long time to come. ${ }^{10}$ What, then, is the task of education for our times for a future such as that just outlined? Is it possible to educate and to confer dignity and the worthiness of a calling to this enterprise when there is so little to hope for, and when the inspiring ideals and aspirations of modernity have spent their force?

In a world beset by such momentous problems and facing forms of brutality that weigh on us all the more painfully as so much had been put in place to make life more peaceful, just, and even enjoyable for many people, what are the possibilities that can be invoked and that can become a promise of a life to come for people? When there is so little that inspires hope, what are the grounds of and for hope? This is an old question, and I suggest we must return to it. We have to return to an old connection, that between hope and despair. This is a theme that has always been linked with an awareness of human mortality and finitude.

The hopes for emancipation connected to the classical modernist position were, of course, designed to overcome the pessimism connected with the awareness of mortality and finitude. As problematic as the classical modernist or emancipatory position may be, one cannot simply sidestep it or subordinate it to more particular concerns such as those raised by some forms of postmodernist thought and social analysis. For much of postmodernist and post-structuralist philosophy has the disintegration of the classical modernist position as its theme. It actively contributes to its demise, as, for example, in the case of the work of Foucault and Derrida. These philosophies may thus once again give rise to forms of pessimism and a lack of confidence in human powers, which was always connected with the fear of mortality. ${ }^{11}$ But the critical pedagogy of Giroux (and Aronowitz) takes a postmodernist 
turn without facing the full dimension of the conflict at issue. Incorporating postmodernist thought, this pedagogy wishes to retain an emancipatory perspective, and argue for education for critical citizenship (Giroux, 1989), while neglecting the fundamental challenge of postmodernist/poststructuralist philosophies to this perspective. Thus there occurs an identification with specific critical concerns, with the critiques of racism, sexism, and homophobia, to name the most frequently mentioned ones. Education (as understood by this form of critical pedagogy) is to help overcome these problems.

Undeniably racism, sexism, and homophobia exist, as do impoverishment and exploitation. And Giroux and others are right when they argue that educational efforts must be made to address them. But when these authors argue for a new kind of public presence for those pushed to the margin or lacking a voice, ${ }^{12}$ they fail to integrate these justifiable commitments with an overall account of the societies in which these deficiencies occur. And they create unrealistic expectations, while also ignoring the ordinary requirements of schooling (such as initiation into forms of knowledge).

Thus they fail to note that:

1. The majority of populations in many countries (including a considerable number of countries in the third world) expect education (formal education) to help them improve their socioeconomic position.

2. An approach toward education, be it as theory or as a plan for practical reform, condemns itself to failure if it does not find a place for these aspirations. Working class immigrants in North America, such as Hispanic, North African, Turkish, and EastEuropean "guest-workers" and resettled individuals and families in Western Europe will expect education to help them consolidate their position.

3. There is absolutely no point to attempting to "politicize" these populations such that they first and foremost respond to issues of sexism and racism. They simply will not respond as long as they have some hope to attain a better and more secure future. The sacrifices connected with immigration, the loss of an ancestral home or even a culture are seen as investments into a future that therefore must provide compensation for the losses and sacrifices incurred.

Realistic considerations such as these would compel one once again to examine the modernist project and to find ways to incorporate a heightened consciousness in it of the issues raised by the "cultural left"-to use a phrase of Searle's (1990)-of sexism and racism, for example. A critical pedagogy of this kind might once again consider a 
social-democratic project of reform and change rather than create the impression of a hyperradicalism that has nowhere to go in practice. It might want to face the implications of the retreat from the welfare state compromise of the recent past that one can observe in several countries. It might attempt to integrate itself into efforts to maintain and develop elements of this compromise. I argue for this position for a number of reasons. First, there is a retreat to be noticed, in North America and Western Europe, from the welfare state and the policies of social support connected with it, on behalf of calls for the renewal of competitive, free-market capitalism. International competition between large trading blocs exacerbates this condition. Various kinds of subsidies and subtle policies providing equilibrium and balance between diverse economic interests are now questioned or removed altogether (Block, Cloward, Ehrenreich, \& Fox Piven, 1987). This may lead to increasing social conflict. Second, in most poorer countries in the world, a minimal form of the welfare state would add considerably to the basic well-being of their populations, more frequently simply to their survival. But the emphasis on international competition, of which the creation of large free-trade zones is just a part, makes the achievement of this aim almost impossible. Third, the emphasis on economic competitiveness as a basic and paramount social value puts pressure on social movements and makes it harder to make a case for their emancipatory goals.

I therefore believe that we should think of educational efforts as counteracting the tendency to undermine the fundamental structures of the Sozial-staat (as it is called in German) and to show that social solidarity has been strengthened considerably by its existence. This is preferable to pursuing more radical goals, which only appear to promise something much better than the welfare state compromise and whatever further-reaching possibilities of social transformation it offers.

In order to give force, focus, and perspective to my argument, I address the project of a critical pedagogy (or, as it also is called at times, of a critical theory of education) especially as it has been developed by Giroux in recent years, with the collaboration of others (Giroux, 1989; Giroux \& Aronowitz, 1991; Giroux, 1991).

Most recently these representatives of critical pedagogy have also taken a postmodernist turn, or so they claim (Giroux \& Aronowitz, 1991; Giroux, 1991). It is important to come to terms with this project, because at present hardly any other form of educational theorizing in North America finds wider acclaim in the circles of educational theorists, researchers, and even teachers, that purports to collect and unite various radically critical perspectives in the field of education. These perspectives are those of feminism, racial and ethnic minorities, or of 
all those believing that the deliberate neglect of the poor and the oppressed by the better-off societies is a dangerous and problematic development.

My preliminary remarks indicate that I regard it important to apply a global perspective to situations requiring educational response. It is only then that one can see how problematic the economic and political predominance of the wealthier countries can become. As one thinks along these lines, one can more readily determine whether the move away from the traditions of modernism makes sense or whether a cautious and disillusioned, but nevertheless morally and politically determined defense of some of its core values still is preferable.

In his book Theory and Resistance in Education: A Pedagogy for the Opposition (1985) Giroux proposed that a radical pedagogy (I take this term to be used interchangeable with the term critical pedagogy) "needs to be informed by a passionate faith in the necessity of struggling to create a better world" (p. 23). It is said to need a vision, looking to a new set of human possibilities. The means for doing so are said to be the construction of public spheres outside those fashioned by the primary institutions of the liberal state. These alternative public spheres are to be found in the "various organizations, clubs, cultural activities, and media productions" developed by the English working class (p. 240 ${ }^{13}$ or in worker education in the United States. And now it is pursued in the newer social movements (feminism, antiracism, and by all those who take an interest in school democracy and the involvement of marginal groups in the control of curriculum and school policy). The "Taylorization" of the work of teachers, the cellular, classroombound nature of their work, is to be challenged. Teachers are to reach out into the community and participate in the formation of alternative educational circles and activities.

Citizenship education, on which Giroux puts much emphasis, is to become a practice of civic courage (1989, pp. 59-60). This is said with reference to Agnes Heller, and a practice of anticipatory reasoning, so to speak, one that is oriented to new and better possibilities of social life. The education preparing for these attitudes challenging existing forms of social and even intellectual discipline places a strong emphasis on critical reasoning and insight into structural and ideological forces, as well as into the patterns of social reproduction, while also attempting to channel forms of resistance existing among minority and subordinate student groups toward more coordinated forms of political action.

Thus it is clear that what is at issue here is a radical political project that is to transform teachers into change agents and schools into sites of radical contestation of the meaning of social existence. So far, so good, one might say. This form of a critique of schooling and a radical 
pedagogy simply enlists the critical analyses and visions of certain social theorists (such as the Frankfurt school theorists primarily, but also of Althusser and Bourdieu, Mouffe and Laclau) into the service of an educational project that ties learning, that is, the systematic study of approved subject-matters and the development of insight through this study, to the definite purpose of transforming a society into a more complete "economic and social democracy" (Giroux, 1991, p. 2).

When one assigns such an aim to pedagogy, one is indeed thinking from within the modernist, radical Enlightenment, as well a Marxist or possibly critical theoretical tradition. And critical pedagogy as inspired by the latter or by Freire's work are parallels that suggest themselves. This holds even if an analysis is lacking that would warrant the pursuit of such a radical pedagogy. This analysis would, for example, try (a) to show exactly what importance schooling and also postsecondary modes of education have for the self-maintenance of developed industrial societies; (b) to identify and discuss the variety of expectations brought to education by the numerous social groups either interested in or contesting its merits; (c) to consider the political power of teachers and their access to cultural and social influence; and (d) to take great care to analyze the possible relations to education that various disadvantaged and underprivileged groups might have.

All these are sober and time-consuming tasks. Their proper consideration requires patience and certainly more than enthusiasm for change, which Giroux so frequently expresses, without ever noticing that what he proclaims as desirable often is no more than empty, formula-like talk of possibilities of transformation that will shift in meaning depending on who or which social group makes it its own. It comes as no surprise in this context that Giroux, in his hasty appropriation of Frankfurt school thought, hardly ever attends to the analytical discussions surrounding the very meaning of possibility; ${ }^{14}$ nor does he notice that philosophers such as Horkheimer and Adorno were hardly enthusiastic supporters of the kind of activism that Giroux espouses. Thinking through their positions as well as Habermas' careful examination of the very possibility and plausibility of critical theory itself as a viable social theory might have made Giroux, and could make anyone, doubt the fruitfulness of an activism that is so impatient that it cannot respond to the depth of disillusionment with any major radical project of social reform that has become the hallmark of all major politics in the developed industrial societies after the World War II.

It would require that one probe more deeply and thoroughly what the pressures are that produce tensions and conflicts in schooling at present and why. One would hold a propensity toward activism in check until a more careful accounting of the situation has been done. 
And taking account of the global dimensions of social conflict that I mention in the beginning, especially the ever pressing conflict between rich and poor nations, might make one wonder what emphasis to place on educational alternatives, of which one can say with great certainty that they will not even make a dent in the overall structure of social and economic organization and that they will not affect the forms of social and political control that regulate access to education and its very organization. Where there are powerful forces at work to keep education in line and subject to the systematic goals of the United States as a world power, as is the case in the United States (at least as represented by its government since the Reagan/Bush presidency), there is hardly much room to introduce radical and drastic changes in schooling unless, of course, they at least seem to fit with the overall agenda in some way. Thus curricula in the United States can incorporate issues of women's equality and even feminism, or ethnic underprivilege and racism. But they may not touch some of the central convictions of American democracy-the basic and widespread conviction that as a society the United States represents what is best in the ensemble of human aspirations to a good and fulfilling life.

Theorists of radical or critical pedagogy ought to face the depth of these convictions and thus also the despair, the real despair, of those who, while constantly faced with proclamations of these convictions, know from their life experiences that they are neither the addressees nor the intended subjects of these proclamations. A critical pedagogy, therefore, has to be highly culture- and society-specific. In the United States, for example, it would have to take on and call it into question the belief that there is something special about being a citizen of the United States. It would have to make reference to principles that hold beyond the boundaries of this society and state. But this, of course, raises the issue of universalism, which so far has not been faced in Giroux's critical pedagogy.

And now this pedagogy has taken a postmodern turn. We can hardly expect this step to contribute to an improvement of the discussion. Rather, one may express some apprehension that the endeavor may deteriorate, that it will dissipate the potential that it had for a theory that could situate educational institutions in an overall theory of the development of late capitalist societies. It will lose the capacity to propose definite steps for a determined educational practice, a pedagogy, that might counteract some of the problems that we encounter in the developed world, while also pointing to the larger problem of the existence of a world of massive impoverishment and suffering beyond the hegemonic societies and states of the Northwestern hemisphere. Transition points could have been named in this context: transitions from a perspective internal to the developed world to one including an awareness of these other, so much less fortunate regions. 
Indications for merely a further increase of confusion can be found in Giroux's recent book, (1989), having the ambitious and promising title Schooling for Democracy: Critical Pedagogy in the Modern Age. This, of course, is an odd title given the turn toward postmodernism already being prepared for in this text. But even more so, the title invites comparison with one of the greatest books in educational theory written during this century, Dewey's (1916) Democracy and Education. One might argue that Giroux's work would have been greatly improved had he really worked through the Deweyan and progressivist positions, thus bringing to bear arguments derived from critical theory against Dewey, some of which he identified in Theory and Resistance in Education (1985). But what then is the significance of the postmodern turn in educational theory?

One is warned that this may be a most problematic undertaking when one considers that in Schooling for Democracy (Giroux, 1989) reference is made to Ernst Bloch and Walter Benjamin. Benjamin's (Arendt, 1969) frequently mentioned Theses on the Philosophy of History are alluded to as expressing what history could look like when written from the point of view of the victims (p. 40). In Giroux's interpretation, this perspective is the one to be adopted in radical educational theory. This is an interesting suggestion, for it could entail the formulation of a definite pedagogy. But this possibility is immediately occluded insofar as Benjamin's and Bloch's messianic and simultaneously secular utopianism are interpreted to entail "an appropriation of history steeped in a commitment to democracy, justice, and equality" (p. 40). Here it is forgotten that Benjamin can hardly be said to have argued for either democracy or equality. Rather, he wished to defend and renew revolutionary Marxism and revolutionary class struggle against social democratic incrementalism. It was justice, rather than democracy, that he wanted. He therefore alluded to the unwillingness to forget, the desire for revenge, as a basis for a class-based politics to be pursued by the oppressed and injured classes.

Benjamin's shocking and painful reflections may be regarded as completely opposite to the developmental vision put forward by Dewey in his early work, as well as opposite to the social democratic orientation of American progressivism in education. They also constitute a bridge to the emphasis on the frequent violations of bodily and personal integrity occurring in contemporary society, which characterizes poststructuralist social theory, as in the case of Foucault (Habermas, $1989 \mathrm{~b})$. A productive assimilation of postmodernism would have been possible on this basis. In part, this is Giroux's intention. He and Aronowitz say, in the recent text Postmodern Education, that "postmodernists are arguing for a plurality of voices and narratives" (Giroux \& Aronowitz, 1991, p. 69). And they continue: "Postmodern discourse is attempting, with its emphasis on the specific and the 
normative, to situate reason and knowledge within rather than outside particular configurations of space, place, time, and power" (p. 69).

And Aronowitz (Giroux \& Aronowitz, 1991) states that postmodernists abandon the will to

scientificity, science as a set of propositions claiming validity by any given competent investigatory [sicl. What postmodernists deny is precisely this category of impartial competence. For competence is constituted as a series of exclusions, of women, of people of color, of nature as a historical agent, of the truth value of art (p. 69).

Thus we may infer that critical pedagogues who have turned postmodern will regard education and pedagogy as an effort to overcome the exclusions referred to above. They will express partiality for the victims of gender, race, and class oppression and emphasize popular culture and cultural struggles in general as the terrain where the new struggles for empowerment are to take place. But what are we to make of this partisanship? How does it compare with Benjamin's emphasis on a perspective on history, deeply formed by the remembered experience of violation? Does Benjamin's argument and vision not entail a partisanship for one principle only, the principle that basic violations of human dignity and personal integrity may not occur? And, if they have occurred, then they may not be forgotten? For if they were to be forgotten, any situation created on the basis of this forgetting would only reconstitute the already perpetrated violence and injustice. It would make iniquity and brutality acceptable, rather than reject and overcome them. It is the intransigent denial of any sort of accommodation that makes Benjamin's position so attractive and desperate. But experiencing the conflict generated by it one acquires a profound understanding of the need for a radical politics and a corresponding form of education, the development of critical consciousness, to speak with Paulo Freire. It may include an awareness of what may not even be possible in human history, the vindication of all the injustice that has occurred in human history. "Redemption" may be impossible. This thought might also set limits on a radical political project as well as on critical pedagogy.

Adopting Benjamin's determined defiance of history as it has been, and continues to be, may require a definite stance against postmodernist flirtations with the politics of difference and an epistemology of partisanship and partiality. For Benjamin endorses partisanship for the oppressed and victimized as an overriding principle from which everything else follows. Thus he endorses a universal principle as valid: Violations of the personal and bodily integrity of human beings are to be avoided at all costs. No society that accepts such violations can be said to be good. Indeed, only the society that can fully vindicate the suffering of past generations in its own design for the present genera- 
tion deserves to be called humane or, one may say, emancipated. Remembrance of the past must be preserved in the present. This is a religious position as much as a secular eschatological one. It radically opposes any accommodation to the strategic games of power politics so common even among minority groups and their attempts to make their voices heard in the plurality of voices in liberal democratic states. (And Giroux, for example, is not clearly resisting this form of accommodation under the guise of arguing for the inclusion rather than exclusion of minority voices.)

Thus, if one were to follow Benjamin, one would have to argue for a partiality that also includes a universal view, a principle that holds whenever oppression has occurred. This oppression is to be undone, and in undoing it is to be remembered as the unforgettable. It has to be made clear that a critical pedagogy endorses such a principle and derives its legitimacy from it. The postmodernist turn in critical pedagogy leads to confusions and uncertainty if this pedagogy does not clearly endorse such a principled view, no matter how elusive. Giroux and Aronowitz (1991) are at least partially aware of this. But they do not sufficiently work through the relevant problems. Therefore, I turn to a last set of arguments addressing the critical pedagogical attempt to have the best of both modernism and postmodernism, to want to distinguish between reactionary and progressive possibilities in both. First of all, the terminology employed by Giroux and Aronowitx indicates confusion. Which discourse would enable us to distinguish between reactionary and progressive possibilities in the postmodern criticism of culture? And why are we to make a shift to culture rather than to attend to the now-classical theme of democratic development, that is, of a politics of democratization that also addresses political processes directly? Why should we not think, together with Benjamin, in terms of a critical theory of education that retains a radically Utopian perspective with respect to the continued existence, and repetition, of injuries and violations of the integrity and self-respect of persons? And would this not entail a conception of the human being and of just social relations that has universal validity, at least in principle?

In the introduction to a recent anthology Giroux (1991), in characteristically grandiose manner, suggests that "modernism, postmodernism, and feminism represent three of the most important discourses for developing a cultural politics and pedagogical practice capable of extending and theoretically advancing a radical politics of democracy" (p. 5). While generally acknowledging that these "three discourses" are "internally contradictory, ideologically diverse and theoretically inadequate" (p. 56), Giroux believes that they offer possibilities to rethink the relation between schooling and democracy, when "interconnections between both their differences and the common ground they share for being mutually correcting" (Habermas, 1989b, pp. 5-6) are explored. 
And as if such claims and such a program for educational change, for education as a means for "self and social empowerment" (p. 56) were not large enough, we learn in the same essay that

a radical pedagogy and transformative politics must go hand in hand in constructing a vision in which liberalism's emphasis on individual freedom, postmodernism's concern with the particularistic, and feminism's concern with the politics of the everyday are coupled in democratic socialism's historic concern with solidarity and public life. (p. 56)

This is a list that invites amusement, at the naivete and arrogance involved, or the lack of moderation and respect for the work of others. How can anyone believe that socialism, the emphasis on plurality in alternative projects for radical democracy (such as Laclau's and Mouffe's), and liberalism are all compatible? One merely needs to add that Giroux still adheres to a critique of technological rationality, that justice, equality, freedom are significant values for him, and that Eurocentrism, racism, and sexism are to be attacked and overcome by critical pedagogy. And all this is, in some way, to lead to the establishment of schools adequate for the times.

Clearly, only an enormous lack of discrimination and of care with thinking can lead to the construction of a monster that does not merely overburden any conceivable politics [at present in North America] geared toward the further development of democracy, and indeed, its principled realization. Is it inconceivable that any teacher who, according to Giroux, is to function as a critical intellectual can make sense of it? It would be enough for an educational theorist and researcher such as Giroux to patiently work out models and practices contributing to a more democratic, fairer form of instruction in the schools, or to argue for the establishment of humane schools in areas where schools have become like prisons. One could also react to the proposals made by minorities, such as Blacks, Hispanics, Native people, East Indians, Chinese, Japanese, who ask that their cultural heritage and their social experience become part of a revised curriculum. We know that even these groups have a variety of expectations regarding schools and the curriculum within them. Certainly none of the concrete, specific problems that schooling poses and that make up community politics with respect to schooling can be addressed with any greater clarity when one derives one's arguments from critiques of metanarratives, of the "occidental" concept of reason, or of "male-dominated, Eurocentric" theories of universalizability and reason.

This much is clear: some of the arguments regarding minority rights, or regarding the relation between national culture and a world society, or similar arguments, have to be made in terms of principles. And as soon as principles are at issue, there arises the question as to whether a principle does indeed hold universally. Whenever we enter into a 
process of deliberation, as citizens in democratic societies participating in decision making processes do (whenever they do), we accept that these rules or principles are to be regarded as the best outcome of the process of deliberation, which we can consider more adequate to a larger number of people and their needs. At such a point we have at least accepted the possibility of the universalization or universalizability of a norm; it may just be the norm, for example, that every person or human being be treated equally, at least in principle, and that therefore everyone, no matter of what origin, creed, gender, or race has the right not to be subjected to physical or psychological abuse. One might operationalize this by referring to, for example, the Universal Declaration of Human Rights (United Nations) or other international Human Rights Convention. Existing practices in a given society could be compared with these.

Giroux does not show much appreciation for these well-known difficulties, with the consequence that he is hardly in a position to give much support to teachers faced with the relevant practical dilemmas and challenges. Authors writing in the manner of the new postmodernist critical pedagogy write with great self-indulgence and for an audience of like-minded academics who thus contribute to their own ghettoization. They write as if they were social theorists or philosophers, but they do not expose themselves to the criticism of professionals in these fields. They write about pedagogy and as critical educators. But they are utterly unresponsive to the needs of day-to-day practice in concrete and real educational settings. They endorse sweeping criticisms of inherited cultural traditions and ways of thinking without really participating in the deconstructive work required. They thus alienate themselves, and the teachers they may train and influence, from a critical treatment of these traditions themselves. They present as an accomplished fact that we now live in a new age, a postmodern age, and that there is little to be relied on in the inherited traditions of criticism, scholarly care, and scrupulousness, or of intellectual and scientific communication, to which one could turn in order to develop the intellectual and critical capacities of teachers as well as their social responsiveness. In short, they tend to spread confusion.

What, then, might be required of a critical pedagogy? This question leads to my concluding comment. In my view, the tasks of a critical pedagogy can only become visible if one leaves the fashionable discussion about postmodernism aside and asks oneself what the task of education could be. I believe that education is to help people achieve a position in which they can lead their lives knowledgeably, responsibly, and with some chance of attaining happiness. Theirs should be a life where they can enjoy the fellowship of others and approach common tasks cooperatively and in the hope that they can come to terms with 
the problems that may arise without resorting to violence and force or to deception and manipulation.

Whatever knowledge is pursued, or whatever intellectual or cognitive effort may be required, it should be done with all these concerns in mind. In pursuing such a project of self-enlightenment (as I would like to call it) for the sake of establishing a peaceful and equitable mode of existence among human beings, one will, of course, encounter numerous problems. Not the least of these is the fact that society does not easily encourage it. Thus there is no need to engage in grandiose social theorizing in order to put critical pedagogy on the right path. There is no need to talk about metanarratives, foundationalism, or postmodernist cultural analysis. For we still need the modest goal of understanding why the realization of a life lived cooperatively, peacefully, responsibly, and with understanding and support of one another is so difficult. It is at this point where the controversy about the limits of the modern age, of European rationality, and about the postmodernist critique may become important, depending on the questions we need to ask and the explanations required.

One question to be asked is how pedagogy differs from politics. Major educational theorists have always understood this difference. Giroux (and Aronowitz) as well as some other postmodern "critical" pedagogues no longer recognize the difference. Any pedagogy is a kind of politics. But this is not the entire truth. Clearly, educational efforts have a political dimension. Politics is, indeed, involved in the distribution of access to knowledge and in its very definition. Postmodernists frequently draw our attention to all this. But educational efforts also have a normative sense. We should examine what view of the world is entailed by this sense and which view of the practical possibilities of human beings to have impact on their situation it entails. Thus one will be able to distinguish pedagogy from politics and avoid simply politicizing pedagogy. Educational efforts require solidarity, freedom, and practice in order to succeed. As such they begin from assumptions that hardly work in politics.

Politics as a practical activity requires strategic calculation. Strategic thinking is integral to politics, but it is not integral to educational pursuits. For the latter always demand the other's, the learner's, knowing participation. Thus education may be political, and it certainly has political aspects, but it also aims at insight, critical knowledge, and self-knowledge. As such education differs from politics, even if it has political purposes. Politics does not always appeal to insight and understanding in order to achieve this aim, but the educational effort must. It has to develop and appeal to insight. Therefore, educational theorists and critical pedagogues have to accept the obligation to think and speak clearly, to be mindful of the fact that not everyone is as much at 
home in a particular realm of theory as a particular writer may be. They have to develop communication rather than hinder it. Educators are not politicians; and to educate may be an action with a political dimension, but it is not the same as engaging in politics. This difference must not be blurred. For a thoroughly politicized education will simply defeat its own purposes and become indoctrination or get pushed aside as attempting to introduce themes into education that are alien to it. This problem is not solved by employing postmodernist rhetoric. Such rhetoric leaves us with the impression that the history of critical thought and critical reflection that have been integral to educational thought during the age of modernity no longer matter. Without these traditions and without a reflective confrontation with them one no longer understands the point of educational efforts in contemporary societies. Education must always be concerned with the development of consciousness rather than with its constriction. Postmodernism is ambivalent on this issue, as is a critical pedagogy attempting to incorporate it and thus in danger of losing itself in it.

Notes

1. I would like to thank two anonymous readers of this paper for their critical comments and stylistic corrections. I have found them most helpful.

2. Searle's article itself is informative and indicative of a well-considered liberal position in American University Education. This holds even if he frequently appears to misunderstand or misrepresent some of the more recent and radical points of view.

3. These forms of "oppression" and their critique largely make up the content of the new and complex school of critical pedagogy, represented by authors such as Giroux and others. I turn to their works in the subsequent discussion. The classic source of critical pedagogy is Freire (1970). It must be remembered, however, that Freire spoke from a definite third-world context and position and developed his philosophy of education and pedagogic theory on the background of a very practical endeavor: the campaigns for literacy education in various Latin American countries.

4. The development of adult education in Scandinavia, Germany and England appears to be linked with this process of social mobilization. Much of it initially was sponsored by the union movement.

5. One finds many references to education as a socially mobilizing force in the writings of theorists of the Third World since the 1950s (and sometimes before), such as in the texts of Gandhi and Nehru (India), of Mao Tse Tung (China), of Hamilcar Cabral and Julius Nyerere (Africa) or of Latin American revolutionary movements (Che Guevara, Freire, the Liberation Theologists).

6. This theme runs through much writing in feminist theory. As far as I know it was openly expressed for the first time by Mary Wollstonecraft in England during the 17 th/18th century.

7. See Horkheimer and Adorno, 1944. They show how mastery of the natural world and the regulation (and exploitation) of human beings belong together into one cognitive system. They argue that the emancipatory goals of the Enlightenment turned into their opposite in the 20th century; they thus make them visible in their coherence. This text has once again become highly significant in the recent North American debates about modernity and postmodernity. See Horkheimer/Adorno: Dialectic of Enlightenment (1972).

8. Thus one could argue that Habermas (1981) attempts to establish the need for communicative rationalization of the life world because, as he sees it, there is a 
need for it to keep pace with economically and administratively driven systems rationalization. This is an old theme in Habermas' work derived from Marx and Dewey and entails the view that communicating citizens of the "developed" societies of the Northern Hemisphere need to take charge of the process of social development as a whole. Habermas' entire theory appears to be designed to reject the defeatist views of cultural pessimists and others who want to take leave of modernity and do not (because problems abound) see the gains made during this historical epoch.

9. Giroux's proposals for the reformation of schools, the creation of "sites" of critical discourse in them, or his proposals regarding teacher education all proceed from the assumption that schools have a major function to play in the reconstitution and reconstruction of society. He thus continues in the tradition of American progressivism since John Dewey. But the question is avoided by him about what changes in American society are needed, for schools (and teachers) to be able to undertake these new and very demanding tasks. To what extent can schools, for example, carry out the struggle against racism when the entire environment around them hardly responds with vigor and clarity to this disastrous phenomenon in American society? Giroux does not sufficiently concentrate on the need to create a broadly based political movement that might also sustain a movement of educational reform. He thus inherits a problem endemic to North American education, whereby educational institutions are to carry the major burdens of social reform rather than politics and political and economic institutions.

10. Much of Heidegger's philosophy has this thought at its center.

11. Major poststructuralist philosophers, such as Derrida and Foucault, appear to remain ambivalent regarding this theme. But it is hard to see how a political or social movement could draw inspiration from them.

12. Giroux speaks of education for critical citizenship in this context (1989).

13. Giroux here refers to the famous study by E.P. Thompson: The Making of the British Working Class.

14. I take all of Habermas' later theory to be an attempt to work out what could be meant by possibilities of transformation in late capitalist societies and to argue that normative and empirical considerations need to be distinguished, as they were not by Marx, in order for such a theory to succeed.

\section{References}

Arendt, H. (1969). Illuminations. Walter Benjamin. New York: Schocken Books.

Block, F., Cloward, R.A., Ehrenreich, B., \& Fox Piven, F. (1987). The mean season. The attack on the welfare state. New York: Pantheon.

Bloom, A. (1987). The closing of the American mind. New York: Simon and Schuster.

Dewey, J. (1916). Democracy and education. New York: Macmillan.

Dewey, J. (1948). Reconstruction in philosophy. Boston: Beacon Press.

Freire, P. (1970). Pedagogy of the oppressed. New York: Herder and Herder.

Giroux, H.A. (1985). Theory and resistance in education: A pedagogy for the opposition. South Hadley, MA: Bergin and Garvey.

Giroux, H.A. (1989). Schooling for democracy: Critical pedagogy in the modern age. London: Routledge.

Giroux, H.A. (Ed.). (1991). Postmodernism, feminism, and cultural politics: Redrawing educational boundaries. Albany, NY: SUNY Press.

Giroux H.A., \& Aronowitz, S. (1991). Postmodern education: Politics, culture, and social criticism. Minneapolis, MN: University of Minesota Press.

Habermas, J. (1981). Theorie des Kommunikativen Handelns (vols. 1 and 2) Frankfurt: Suhrkamp.

Habermas, J. (1989a). Die Neue Unbersichtlichkeit. Frankfurt: Suhrkamp.

Habermas, J. (1989b). Der Philosophische Diskurs der Moderne. Frankfurt: Suhrkamp.

Habermas, J. (1991). Staatsbürgerschaft und nationale Identität. berlegungen zur europischen Zukunft. Unpublished manuscript. 
Horkeimer, M., \& Adorno, T.W. (1944). Die Dialektik der Aufklrung. Amsterdam: Querido.

Horkeimer, M., \& Adorno, T.W. (1972). Dialectic of enlightenment (J. Cumming, Trans.). New York: Seabury Press.

Misgeld, D. (1985). Education and cultural invasion: Critical theory, instructional objectives and the pedagogy of the oppressed. In J. Forester (Ed.), Critical theory and public life. Cambridge, MA: MIT Press.

Misgeld, D. (1991). Moral education and critical theory. From the First World to the Third World. In Kurtines \& J. Gewirth (Eds.), Handbook of moral behavior and development. Volume 3 (pp. 163-178). Hillsdale, NJ: Erlbaum.

Searle, J. (1990, December 6). Storm over the university. New York Review of Books, XXXVII. 